\title{
AGORA QUE A TITI SE FOI
}

\section{NOW THAT TITI IS GONE}

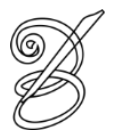

\section{Rafael Ginane BEZERRA*}

Universidade Federal do Paraná

Curitiba, Paraná, Brasil

Resumo: Condensando várias décadas, "Agora que a Titi se foi” articula complexos jogos temporais em relação à vida da protagonista, da sua família e da história argentina. Inicialmente, nos anos 60, vislumbra-se a infância de duas mulheres: "Titi", presente no título e nomeada recorrentemente nas páginas do conto, e sua irmã, a narradora que não chegamos a conhecer o nome. Em seguida, tendo como pano de fundo os anos de maior violência da ditadura argentina, ambas são retratadas em plena adolescência. Por fim, relata-se a desconcertante descoberta da maturidade num cenário em que muitos dos personagens se foram, mas cujos fantasmas insistem em aparecer.

Palavras-chave: Lilia Lardone Literatura argentina. Contos. Tradução. Mulheres.

Abstract: Going through several decades, "Now that Titi is gone" articulates complex temporalities related to the protagonist's life, her family and Argentine history. In the 60s, it presents the childhood of the woman mentioned in the title - and several times named in the short story - and her sister who is the narrator we don't get to know the name. Thereafter, the youth of these sisters is portrayed during the most brutal period of the Argentine military dictatorship. Finally, the bewildering discovery of adulthood is narrated in a context where many of the characters are gone, but their ghosts insist on being present.

Keywords: Lilia Lardone. Argentine literature. Short story. Translation. Women.

RECEBIDO EM: 10 de outubro de 2019

ACEITO EM: 26 de fevereiro de 2020

PUBLICADO EM: março 2020 
o conceder entrevistas, Lilia Lardone (1941, Córdoba - Argentina) fala de sua
experiência leitora, de sua atuação como formadora de docentes para o trabalho
com literatura, do seu papel como coordenadora de oficinas de escrita e da sua ligação profunda com amigos e familiares. Discreta e reservada, enfatiza que a escrita representa apenas um dos seus vínculos com o mundo, não necessariamente o mais importante. O seu primeiro romance, Puertas adentro (inédito no Brasil), foi publicado quando ela tinha cinquenta e sete anos, depois de ter contribuído para a formação de inúmeros escritores e escritoras. Sua obra, que contempla narrativa, poesia, literatura infanto-juvenil, ensaios e antologias, tem como marca a dor e o clima asfixiante da vida interiorana, os claroescuros da existência e a complexidade dos personagens femininos. Ponderando sobre sua produção em termos de gênero, ela se mostra relutante em aceitar o rótulo de "literatura feminina" e ressalta que, antes de tudo, segue a trilha de uma literatura que a desafie. Essas marcas, à perfeição, podem ser experimentadas em seu conto “Agora que a Titi não está", que integra o livro Vidas de mentira y otros relatos (2003). 


\section{AGORA QUE A TITI SE FOI}

Oh, se neste anoitecer o vento também tocasse em você instrumento desafinado, coração. Eugenio Montale

Mais que um negócio, os relógios eram uma obsessão. Eu não podia me aproximar do lugar onde ele trabalhava, sempre em silêncio, e somente a Titi podia preencher os cartõezinhos que ele pendurava em cada relógio, depois que os clientes iam embora. Ela até tinha permissão para escrever com lápis copiativo nos livros-caixa. Quando terminava, com uma mancha violeta nos lábios, ela aparecia sorridente no pátio, na calçada, onde eu estivesse, e insinuava querer apenas um pouco de proximidade, apesar de denunciar a si mesma com um movimento de olhos, uma tensão súbita nos músculos do pescoço, algo que sempre me indicava a quem era destinada aquela mancha.

Antes de começar o conserto dos relógios, o pai acomodava cuidadosamente a almofada de croché que a mãe tinha tecido, Pobre coitado, precisa ficar tanto tempo sentado, ajustava a flanela cinza ao cinto e retirava uma por uma as ferramentas da gaveta, deixando-as sobre a tela de veludo escuro. Em seguida, colocava o monóculo, alisava o cavanhaque e acendia a lâmpada que ficava alguns centímetros acima da sua testa para iluminar bem as peças. Da porta, eu pensava que a pinça era um prolongamento do seu indicador, uma unha metálica comprida que ele usava com movimentos precisos para esgaravatar as entranhas dos relógios. De hora em hora, invariavelmente, ele tirava o monóculo, se levantava para ajustar os relógios pendurados por todos os lados e, como o chamado do cuco me avisava, eu corria para ver. A primeira a sair era a bailarina, loira como a Titi, girando sua saia curta. Depois, vinha o lenhador barbudo que agitava o machado, qual bandeira de papel, daquelas que a professora distribuía para comemorar o 25 de Maio. O último era o meu preferido, um homenzinho careca, de bigode, que martelava um sapato feminino. Por que ele martela tanto?, eu perguntava mas o pai, ocupado em mover os ponteiros até corrigir erros imperceptíveis para olhos que não fossem os seus, não me respondia. Atrás de mim, a Titi me dizia para não o incomodar com besteiras.

Às vezes, ao chegar um cliente, eu que brincava na calçada aproveitava para me reaproximar da relojoaria. O som alegre da campainha, um passarinho de bronze que batia as asas, nunca me cansava. Mesmo depois de fechada a porta, o bater de asas continuava devido 
a um mecanismo que jamais compreendi e que, em vão, tentei fazer com que o pai me explicasse. Um dia, a minha insistência o enfureceu a ponto de fazê-lo tirar o monóculo, endireitar-se e me dizer: Você nunca vai compreender. Uma manhã, em São Paulo, foi inacreditável encontrar o mesmo bicho. Ao entrar numa loja, a sonoridade do bronze me deteve. Igualzinho, pensei. Estavam lá o pássaro preso, o pai, o brilho do seu monóculo no olho direito e todos os relógios marcando o tempo que havia passado. Os meus ouvidos pareciam olhos porque, além de escutar, eu via as imagens da relojoaria passando com rapidez. Então, o som foi se apagando e somente o rosto do pai permaneceu. Foi estranho. Nem mesmo as notícias sobre a Titi davam aquela sensação.

Possivelmente, porque eram notícias fragmentadas. Algum conhecido chegava ao Brasil e, seguramente porque a mãe pedia, me telefonava para passar uma mensagem. Eu quase nunca entendia o porquê das meias palavras, Não posso te dizer muito; não sei, mas tua irmã não está; sim, não se sabe onde ela está sendo mantida. Depois, fazia-se um silêncio até que eu perguntava onde diabos estava a Titi. Ou então, eram as cartas escritas em código: Continuamos preocupados com a Titi. E nada mais.

Claro que isso tinha acontecido muito tempo depois da viagem. A espuma se formava na crista das ondas e era difícil acreditar que eu estava lá, vendo o mar azul, sem me cansar do balanço, mesmo quando Cecilia me censurava. Você é jeca, dizia, Até quando vai ficar na água, vamos voltar pro hotel. Eu me arrumava e a seguia, pensando que conhecer o Brasil era a melhor coisa que já tinha me acontecido. Ninguém prestava atenção nos meus cabelos pretos e encrespados, nem nos meus quilos a mais. Ninguém me dizia que eu não parecia ser a irmã da Titi. Depois, conheci o João e decidi não voltar para a Argentina. Você é louca, repetia Cecilia antes de partir, E agora, o que é que eu digo pros teus pais? Por fim, ficou conformada e eu lhe entreguei uma carta para a mãe, Consegui um trabalho fantástico num hotel do Guarujá. A Titi ficou revoltada e me escreveu dizendo, Você não muda, não se importa nem um pouco com o pai e a mãe.

A Titi, que me veio à cabeça anteontem à noite, quando vi na televisão as ruas de Buenos Aires, uma voz falando do Gardel, da Evita, do Che. O que a Argentina poderia ter sido, dizia a voz. Logo pensei na Titi.

A voz constrói histórias. Presto mais atenção e me sento na cama com o controle remoto para aumentar o volume. Um casal dança tango num vagão de metrô vazio. Outro (o mesmo?), se move lentamente num grande salão de baile, também vazio. Outro, seguramente outro, numa doca deserta. Merda, que país triste!, penso e escuto o som do vento que varre o 
quebra-mar do porto de Buenos Aires. E a voz continua: Quando se trata de tango, o homem procura pela melhor dançarina. Nesse momento, vejo a Titi. O tempo se detém, como se o pai o controlasse. Voltem cedo, escutaram?, o pai nos diz da porta. A Titi e eu nos apressamos, Vamos que numa dessas ele se arrepende. Parou de chover. Os olhos da Titi brilham enquanto caminhamos pela avenida Pueyrredón com as amigas dela. Na festa, Raúl a procura. Eles dançam. Claro que a Titi dança bem, com paixão nas pernas e nos volteios. Ela é tão, mas tão leve. Vamos ver se você parece uma pluma como a tua irmã, disse Raúl, insistindo em me ensinar a dançar, na noite em que estreamos o toca-discos Winco. Como eu me atrapalhava, logo fui me sentar.

A Titi também era linda. Loira como a minha mãe, disse o pai em voz baixa no dia da festa de formatura, quando ela apareceu com o vestido azul-celeste.

Ao contrário da Titi, o auge dessa mulher que dança na televisão já passou. Tchau, você perdeu guria, o teu tempo já era. Até mesmo no casamento, apesar de estar ao redor dos vinte e cinco, a Titi parecia uma menina. A foto ficou gravada em minha memória, ela vestindo a bata hindu que ficava maravilhosa com a calça jeans, o Raúl com cabelo e barba compridos, os dois sorridentes, abraçados em frente ao Registro Civil. E naquele verão de 75, escondida com Cecilia, feliz por ter chegado aos vinte e um, pela liberdade de poder ir embora com minhas economias apesar da oposição do pai, eu preparava a viagem ao Brasil. O Raúl e a Titi me repreenderam, dizendo que os tempos não estavam para brincadeira. Logo agora você resolve viajar?, perguntou Raúl, e a Titi disse, Deixa pra lá, é uma irresponsável. Mas, no fim, os dois me acompanharam até a estação de Retiro, Raúl fazendo sinal que queria me dar uma almofada. Quando abri a janela, ele disse: A viagem é longa, vai precisar disso pra bunda não ficar quadrada. E eu quis morrer de vergonha porque já estava de olho num rapaz moreno, sentado no banco de trás. Também me lembro de que a Titi me levou um bronzeador e disse: Cuide-se. Que ridículo, era a última vez que nos víamos e ela me disse: Cuide-se, o sol enruga. E eu ri. Pelo menos se eu pudesse culpar o sol pelas rugas de todos esses anos. É assim: quarenta e tantos anos e o peixe encalhado, como dizia a tia Chela. A tia Chela, será que continua no bairro ou também morreu?

Foi má sorte o que aconteceu com o pai. Justo no ano em que eu tinha ido para a comunidade, meses e meses isolada, apenas fazendo miçangas, preparando a comida e cantando com os outros durante a noite no meio do campo. Até que chegou um entardecer. A chuva caía e, de repente, fui tomada por uma tristeza que não me deixava respirar, uma 
necessidade urgente de ver a chuva sobre o asfalto, de ouvir as buzinas nas ruas de Buenos Aires.

Mas não fui para Buenos Aires. Voltei para São Paulo e encontrei as cartas da mãe amontoadas na caixa do correio. Antes de abrir, ordenei-as por data. A última tinha três meses. Na segunda, ela avisava que o pai tinha sofrido um ataque cardíaco. As seguintes relatavam os cuidados, Precisa ser atendido como uma criança, e era difícil imaginar o pai de cama. Até que uma, com letra tremida, contava que o pai tinha morrido. Eu já sabia antes de abrir, mas mesmo assim li até o fim, Agora sim que fiquei sozinha, dizia. Muito tempo, três meses. Recordei das cartas anteriores, quando as desaparições da Titi e do Raúl se perdiam num emaranhado de palavras. Não diziam, mas era possível ler claramente que eu tinha me salvado por ter viajado ao Brasil, por ter vivido a boa vida, era isso que a mãe queria dizer com: Pobre Titi. Um dia, olhando o mar, João disse: Todos temos fantasmas. Era a resposta para os meus olhos, fixos na espuma das ondas, depois de receber notícias de casa. As cartas também diziam: Não volte, é preciso dar tempo ao tempo. Então desfilavam os relógios do pai, várias esferas azuladas com os ponteiros girando nas mãos da Titi.

O tempo não passava, nem mesmo quando deixamos o Guarujá e fomos para o Rio, no apartamento de um amigo do João. Eu gostava daquela rua no Leblon, das árvores de folhas grandes e polpudas, do Sergio e de seus movimentos harmónicos que destoavam do seu corpo enorme. João, ao fazer as apresentações, me fez prestar atenção na corrente com máscaras prateadas sobre o peito. Cada máscara, uma religião, foi a explicação do Sergio, e eu fiquei pensando. Ele me ajudou a compreender os silêncios do João, seus sumiços, o meu sofrimento quando João desaparecia e eu o imaginava com uma mulher loira, alta e magra.

Um dia, me dei conta de que fazia mais de um mês que não via o João. Chorei muito. Depois, conversei com o Sergio. Eu tinha decidido ir embora para São Paulo, procurar trabalho, começar de novo e precisava do conselho dele. Sangue bom, o Sergio me escutou até de madrugada. Contei tudo sobre a Titi. Também contei que não podia voltar para a Argentina. Não apenas por medo dos milicos, mas também porque não tinha condições de olhar a mãe nos olhos, de olhar a Titi nos olhos da mãe. No dia seguinte, saímos caminhar. Ele disse que me faria bem uma mudança para encontrar meu próprio caminho. É preciso conquistar a liberdade, sussurrou, com as mãos grandes nas prateleiras de uma livraria. Peguei o Livro Vermelho do Mao e disse: Como vendem isso, se os milicos também mandam aqui? E ele me olhou sério: Pouco importa, aqui quase ninguém sabe ler. 
E essa chuva ingrata que não para. Desde que embarquei no ônibus em São Paulo, chove. E agora, continua chovendo em Foz. Uma cortina volumosa de água envolve o ônibus e não posso nem reconhecer a paisagem. Me incomodavam a chuva e o calor, dia após dia, verão o ano todo. Você já se acostuma, dizia o João, mas uma humidade pior do que a de Buenos Aires me invadia. A Titi, por sua vez, gostava do calor. Até nisso éramos diferentes. Titi, minha filha querida, escrevia a mãe, anos depois que os milicos se foram e a correspondência voltou a ser segura. Titi, a mais bonita.

Antes, esta ponte não existia, mas imagino que deve faltar pouco para chegar. Por sorte, parou de chover. Gosto de ver os campos amarelos, os edifícios que aparecem no horizonte, brilhantes em contraste com o céu que ainda está um pouco cinza. Tenho certeza de que a mãe está tirando o barro da calçada. Quase a vejo, praguejando contra a chuva.

Ainda existe a padaria do Tito? E os pais do Raúl, ainda moram na esquina? Como poderiam morar? Sou mesmo uma idiota. Vinte anos e ainda acho que posso saber de alguma coisa.

E, por fim, voltar para quê. Para a tia Chela me dizer que estou gorda, para a mãe voltar a me comparar com a Titi. Como é que eu vou competir com a Titi, agora que ela se foi?

\section{REFERÊNCIA}

LARDONE, Lilia. Ahora que la Titi no está. Vidas de mentira y otros relatos. Córdoba, Argentina: Babel, 2003.

\footnotetext{
* Rafael Ginane BEZERRA - Graduado em Ciências Sociais (1996) pela Universidade Federal do Paraná. Mestre (2003) e Doutor (2009) em Sociologia pela mesma instituição. Realizou pesquisa pós-doutoral (2019) na Universidad Nacional de Córdoba, Argentina. Professor adjunto IV na Universidade Federal do Paraná. Universidade Federal do Paraná, Setor de Educação, Departamento de Teoria e Prática de Ensino. Curitiba, Paraná, Brasil.

Currículo acadêmico: http://lattes.cnpq.br/9365203078252174

ORCID: https://orcid.org/0000-0001-5979-5192

E-mail: rginane@gmail.com
} 